\title{
Comparitive Study on Outdoor and Indoor Forensic Insects encountered on Rabbit Corpses in Upper Egypt
}

\author{
Mohammed Z. Y. Aly ${ }^{1}$; Khaled S. M. Osman ${ }^{1}$; Fatma H. Galal ${ }^{2,3}$, Gihan H. M. Ali ${ }^{1}$ \\ ${ }^{1}$-Department of Zoology, Faculty of Science, South Valley University. \\ ${ }^{2-}$ Department of Biology, College of Science, Aljouf University. \\ ${ }^{3}$-Department of Entomology, Faculty of Science, Cairo University.
}

\begin{abstract}
This work aims to illustrate the forensic insects, their succession patterns and decomposition stages of rabbit corpses in ecologically different sites. The present study was performed on two sites including outdoor, open or roof site, in addition to indoor, closed or ground site of the faculty of science in Qena city for four successive seasons. Results showed eighteen species of necrophagous, necrophilous, omnivorous and accidental insects, of them, five outdoor species, three indoor species and ten common species. The five corpse decomposition stages (fresh, bloating, active, advanced and dry stages) have been observed. Twelve species of Diptera and three species of Coleoptera and Hymenoptera were collected from the carcasses. The dipteran species were the predominant groups on the corpses, whereas the coleopterans occupied the $2^{\text {nd }}$. The most important forensic insects were represented by Sarcophaga carnaria, Wohlfahrtia magnifica, Chrysomya albiceps, Lucilia cuprina, Muscina stabulans, Megaselia scalaris and genus Nasonia. Moreover, the studied calliphorid and sarcophagid flies were the first colonizers to arrive and breed on rabbit carcasses. The rate of corpse decomposition was faster in summer and spring as compared to winter and autumn. Outdoor corpses decomposed faster than indoor corpses. On the other hand, the statistical analysis showed negative temperature and humidity correlation on Sarcophaga carnaria, while both Wohlfahrtia magnifica and Muscina stabulans were affected positively by temperature and humidity, respectively. Therefore, these results are recommended to be taken in Criminal investigations.
\end{abstract}

Keywords: Forensic entomology; Insect succession; Corpse decomposition; Outdoor; Indoor; Egypt.

\section{Introduction}

Forensic entomology is the science interested with studying insects and other arthropods associated with carrions to help in solving criminal cases (Greenberg 1985; Lord et al., 1986a; Lord et al., 1986b; Kashyap \& Pillai 1986; Goff et al., 1986; Goff \& Odom 1987; Goff et al., 1988; Goff et al., 1991; Goff \& Flynn 1991; Lord et al., 1992; Leclercq \& Vaillant 1992; Goff 1992; Lord et al., 1994; Anderson 1995; Anderson 1997). Insects are the first organisms to discovery and colonize a cadaver after death. For this reason the entomologists often use the insects and other arthropods associated with carrions in solving the violet crimes (Bonacci, 2016).

Pathologist can estimate the postmortem interval based on many biological parameters such as lividity, postmortem cooling, rigor mortis and changes in the chemical constituents of body, tissue autolysis, and decomposition due to the bacterial activity in corpse. However, these parameters are not reliable beyond about 72 hours after death (Henssge et al., 1995). However, the entomological method of determining PMI was found to be statistically more reliable and superior when compared to other pathological methods, particularly during later stages of decay (Kashyap \& Pillai, 1989).

Insect succession and cadaver decomposition can be influenced by many factors such as temperature, humidity, season, habitat, time of day, corpse accessibility and its physical position (Williams and Richardson 1984; Tullis and Goff 1987; Hall and Doisy 1993; Tessmer and Meek 1996; Dillon 1997; Anderson 2000b). Many papers have studied the differential effects of season on necrophagous fly activity (Introna et al., 1989 and Chen et al., 1991), insect succession (Archer \& Elgar, 2003) and decomposition (Mann et al., 1990 and De Carvalho \& Linhares, 2001). All these papers concluded that season and habitat have major effects on the assemblage of invertebrates discovered on carrion and the time of insect colonization. Consequently, it is crucial to study the insect activity on carrion in specific geographic areas and different habitats. The present study was designed for investigating the entomofauna associated with rabbit corpses and its succession pattern in relation to decomposition stages of corpse, climatic conditions, and habitats.

\section{A) The Study Sites:}

\section{Materials And Methods}

The study sites were located on the south valley university land in Qena city, Egypt. Study was conducted for one year at two different habitats. For each season, two sites were selected, one outdoor and the other indoor. Sites for carcass placement were chosen on the roof of faculty of science (outdoor environment)

DOI: $10.9790 / 3008-1203074154 \quad$ www.iosrjournals.org $\quad 41 \mid$ Page


and at room on the basement of the faculty (indoor environment).

\section{B) Experimental Animals:}

The rabbits, Oryctolagus cuniculus, are chosen to simulate the soft skin of a new baby and were characterized by a relatively uniform size. The mentioned rabbits were purchased locally with different colors but comparable in size. On the delivery day of each season, rabbits were weighed, and then euthanized with air injection to mimic the normal death case without any chemicals or drugs. After death, the animals were immediately delivered post-mortem to the research sites in an appropriate man-made plastic traps which were designed specifically to allow insect access, but prevent them escaping. A tray containing sawdust was placed under each cage to facilitate the collection of larvae leaving carrions for pupation.

\section{C) Field Protocols:}

Three experiments were conducted in each season. Four rabbit carcasses were placed in each experiment, two at the indoor habitat and two at the outdoor habitat. All efforts were made to keep cadaver disturbance to a minimum during taking samples. Observations, photographs, temperature, humidity readings and sample collections were made daily at varying times of the day according to each experiment. The temperatures and humidity readings were taken with digital thermometer.

\section{D) Sample Handling and Preservation:}

During collection days, representative samples of immature and adult insects were collected from and around the carrion. While all insects observed were sampled, there was a definite focus on flies and beetles. Adult flies were collected by separating the upper part of trap. Adult beetles, immature insects, and other hardbodies crawling insects were collected by hand or with forceps and immersed in $70 \%$ alcohol. For each carrion, approximately 20 larvae were collected from every distinct maggot mass on the body.

\section{E) Data and Statistical Analysis:}

The Student's excel sheet was employed to compare between the temperature and humidity readings for each season separately. Analysis of Variance on SPSS software package (version 16) (SYSTAT statistical program) was used to test the present data. Pearson correlation coefficients and multiple regressions were applied in the present data. Stepwise multiple regressions were used to select the affected variable.

\section{Forensic Catches:}

\section{Results}

During the present study, eighteen species of necrophagous, necrophilous, omnivorous and accidental insects were collected from the indoor and outdoor rabbit corpses for one year from October 2013 to September 2014 and then were identified. These species belong to three orders and fourteen families as shown in (Table 1). Five species of insects of two orders and five families were collected from rabbit corpses placed outdoor only compared to three species of three orders and three families were collected from corpses placed indoor only. Ten species of forensic and non-forensic insects of three orders and eight families were collected from both carcasses placed outdoor and indoor. The most dominant forensic insect observed during the study was represented by the hymenopteran parasite species, Nasonia sp. (64.4\%) of all collected insects and the dipteran forensic species Sarcophaga carnaria which existed all over the studied period.

\section{Seasonal Corpse Decomposition Stages:}

Decay rates of rabbit corpses in different seasons from October 2013 to September 2014 in Qena city, Egypt are shown in table (2). Although the process of decomposition and insect invasion were continuous, it was often described by separate stages, which was characterized by the insect activity at each point in decomposition. All decomposition stages prolonged the highest period in winter and the lowest period in summer. The process of corpse decomposition was divided into five stages as follows:

1) Fresh stage began with the moment of death and continues until the first signs of bloating. No odor or swelling. During this stage, flies of Calliphoridae and Sarcophagidae begin arrive to the corpse and lay their eggs or larvae. (Fig. 1, 2, a).

2) Bloating stage marked the beginning of putrefaction, begins when the abdomen bloat due to the autolysis of tissues and the activity of fungi and bacteria and ends when abdomen deflates due to the releasing of gases. (Fig. $1,2, b)$.

3) Active decay stage started with releasing gases and deflating abdomen. A corpse odor was very strong (Fig. 1, 2, c).

4) Advanced decay stage had an odor that began to fade, most of the flesh has disappeared, some soft tissue still found in the abdomen and the coleopteran species are the predominant (Fig. 1, 2, d). 
5) Dry stage was characterized by disappearing odor and the remains become consistent only of bones and hairs (Fig. 1, 2, e).

\section{Seasonal Succession of Forensic Insects:}

During this study, twelve experiments were conducted on forty-eight rabbit corpses at two different habitats to monitor the insect succession and corpse decomposition through the various seasons as follows:

\section{A) Outdoor and indoor autumn experiments:}

Data recorded in table (1) and fig. (3) showed that $93 \%$ of adult insect individuals representing 3 orders and 10 families were collected in autumn season 2013 from rabbit corpses placed outdoor. However, 7\% of adult insect individuals representing 1 order and 4 families were collected from the corpses placed indoor. Diptera, Coleoptera and Hymenoptera comprised 37\%, 2\%, 61\% of the insect collected from corpses placed outdoor. While Diptera comprised $100 \%$ of the insect collected from carrions placed indoor.

Two species of the adult Sarcophagids, Sarcophaga carnaria and Wohlfahrtia magnifica, were collected from all corpses in both habitats. Sarcophaga carnaria (Fig. 7) was collected in number of 82 and 18 individuals from carrions placed outdoor and indoor, respectively. However, 37 and 4 adult individuals of Wohlfahrtia magnifica (Fig. 8) were collected from carrions placed indoor.

Also two species of the calliphorid adults, Chrysomya albiceps and Lucilia cuprina were collected from all corpses in both habitats (outdoor and indoor). The number of occurrence was represented by 83 and 3 individuals of Chrysomya albiceps (Fig. 9) for carcasses placed outdoor and the other placed indoor, respectively. However, the number of occurrence recorded 56 and 2 individuals of Lucilia cuprina (Fig. 11) for carcasses placed outdoor and indoor, respectively.

One the muscid species, Musca domestica (Fig. 19) with 159 and 10 individuals were collected from corpses placed outdoor and indoor, respectively. While, Megaselia scalaris (Fig. 10) (Family: Phoridae) with 29 and 67 individuals were collected from corpses placed outdoor and indoor, respectively. Physiphora demandata (Fig. 22) (Family: Otitidae) was only collected from carcasses placed outdoor; 36 individuals were collected. Also Anopheles coustani (Fig. 23) (2 individuals) and Scatella sp. (1 individual) were collected only from corpses placed outdoor.

The coleopteran species collected were; Saprinus gilvicornis (Fig. 14) (12 individuals) and Dermestes vulpinus (Fig. 13) (13 individuals) from carcasses placed outdoor only. Of Hymenoptera only Nasonia sp. (Fig. 16) (Pteromalidae) was only collected from carrions placed outdoor (790 individuals) (Table 1 \& Fig. 3).

\section{B) Outdoor and indoor forensic insects during winter:}

As shown from results given in table 1 and fig. 4, 90\% of adult insect individuals representing 3 orders and 9 families were collected in winter season 2014 from rabbit corpses placed outdoor. However, $10 \%$ of adult insect individuals representing 3 orders and 6 families were collected from the corpses placed indoor. Diptera, Coleoptera and Hymenoptera comprised 14\%, 2\%, 84\% and 63\%, 35\%, 2\% of the insect collected from rabbit corpses placed outdoor and indoor, respectively.

One sarcophagid adult, Sarcophaga carnaria was collected from all corpses in both habitats. Sarcophaga carnaria was collected in number of 39 and 12 individuals from carrions placed outdoor and indoor, respectively. Also one species of adult Calliphoridae namely; Chrysomya albiceps was collected from corpses placed outdoor only with 14 individuals.

Two species of adult Muscidae namely; Musca domestica and Muscina stabulans were observed on the corpses during winter. Musca domestica with 47 and 8 individuals were collected from corpses placed outdoor and indoor, respectively. However, 3 adult individuals of Muscina stabulans (Fig. 12) were collected from carrions placed indoor only.

Megaselia scalaris (Family: Phoridae) with 145 and 96 individuals were collected from corpses placed outdoor and indoor, respectively. However, Sepsis fissa (Fig. 21) (Family: Sefsidae) was only collected from carcasses placed outdoor; 3 individuals were collected. One individual of Anopheles coustani (Family: Culicidae) was collected from both habitats (indoor and outdoor).

Three coleopteran species visited the corpses during winter namely; Saprinus gilvicornis (Family: Histeridae), Dermestes vulpinus ((Family: Dermestidae) and Atheta sp. (Family: Staphylinidae). Saprinus gilvicornis (22 individuals) and Dermestes vulpinus (5 individuals) were collected from carcasses placed outdoor only. While, Atheta sp. (Fig. 15) was collected from carcasses placed indoor only (66 individuals). The hymenopteran Nasonia sp. (Pteromalidae) was only collected from carrions placed outdoor (1472 individuals). Camponotus maculates (Fig. 18) (Hymenoptera: Formicidae) with 3 individuals were collected from corpses placed indoor only (Table $1 \&$ Fig. 4). 


\section{C) Outdoor and indoor spring experiments:}

Data given in table (1) and fig. (5) showed that $87 \%$ of adult insect individuals representing 3 orders and 8 families were collected in spring season 2014 from rabbit corpses placed outdoor. However, $13 \%$ of adult insect individuals representing 3 orders and 8 families were collected from the corpses placed indoor. Diptera, Coleoptera and Hymenoptera comprised 15\%, 2\%,83\% and 70\%, 5\%, 25\% of the insect collected from rabbit corpses placed outdoor and indoor, respectively.

The sarcophagid species were represented by Sarcophaga carnaria and Wohlfahrtia magnifica. Sarcophaga carnaria was collected in number of 88 and 25 individuals from corpses placed outdoor and indoor, respectively. However, 3 adult individuals of Wohlfahrtia magnifica were collected from corpses placed outdoor only. One species of adult Calliphoridae namely; Chrysomya albiceps with 32 and 3 individuals were collected from corpses placed outdoor and indoor, respectively. Family Muscidae was represented by three species namely; Musca domestica, Muscina stabulans and Atherigona varia. Musca domestica was collected with individual numbers of 86 and 18 from rabbit carcasses placed outdoor and indoor, respectively. Muscina stabulans was collected from corpses placed indoor only (17 individuals). However, Atherigona varia was collected from corpses placed outdoor only (2 individuals). The number of 90 individuals of Megaselia scalaris (Family: Phoridae) was collected only from rabbit carcass placed indoor only. While, one individual of Anopheles coustani (Family: Culicidae) was collected from both corpses placed outdoor and indoor.

The coleopteran species were represented by two species namely, Saprinus gilvicornis and Dermestes vulpinus. The number of Saprinus adults collected from rabbit carcasses was 19 and 3 outdoor and indoor, respectively. Dermestes was collected with individual numbers of 14 and 5 from carcasses placed outdoor and indoor, respectively. Nasonia sp. (Hymenoptera: Pteromalidae) was represented by 1189 and 56 individuals collected from rabbit carcasses placed outdoor and indoor, respectively. Chalcis sp. (Hymenoptera: Chalcididae) with 50 individuals were collected from corpses placed outdoor only (Table $1 \&$ Fig. 5).

\section{D) Outdoor and indoor summer experiments:}

As shown from results given in table 1 and fig. $6,76 \%$ of adult insect individuals representing 2 orders and 6 families were collected in summer season 2014 from rabbit corpses placed outdoor. However, 24\% of adult insect individuals representing 2 orders and 5 families were collected from the corpses placed indoor. Diptera and Coleoptera comprised 99\%, 1\% and $81 \%, 19 \%$ of the insect collected from rabbit corpses placed outdoor and indoor, respectively. Family Sarcophagidae was represented with two species, Sarcophaga carnaria and Wohlfahrtia magnifica. The number of Sarcophaga adults collected from rabbit carcasses was 10 and 13 outdoor and indoor, respectively. Wohlfahrtia magnifica was collected with individual numbers of 56 and 15 from rabbit carcasses placed outdoor and indoor, respectively. Only one calliphorid adult, Chrysomya albiceps was collected with individual numbers of 42 from rabbit carcasses placed outdoor only. On the other hand, Musca domestica was collected from rabbit carcasses placed outdoor and indoor. The number of adults collected was 92 and 15 , respectively.

Megaselia scalaris (Phoridae) was collected with individual number of 36 from corpses placed indoor only. One Culicid adult, Anopheles coustani collected from rabbit corpses placed outdoor only (69 individuals) and the number of Physiphora demandata adults (Family: Otitidae) collected from rabbit carrions was 35 outdoor only. The Coleopteran species were represented by two species namely; Saprinus gilvicornis and Dermestes vulpinus. Three individuals of Saprinus gilvicornis adults were collected from both carcasses placed outdoor and indoor. The number of Dermestes adults collected from rabbit corpses placed indoor only was 15 (Table 1 \& Fig 6).

\section{Statistical Analysis}

\section{a) Correlation between the environmental factors and the numbers of recorded species:}

By applying the correlation analysis between the numbers of recorded species with the physical factors during the period of experiment (Table 3), it was concluded that the numbers of Sarcophaga carnaria maggots were negatively correlated with temperature. However, the numbers of Wohlfahrtia magnifica maggots were positively correlated with temperature and negatively correlated with humidity. The numbers of Muscina stabulans maggots were negatively correlated with temperature and positively correlated with humidity.

\section{b) Stepwise multiple regression between the numbers of recorded species with the physical factors and the weight of corpse:}

Stepwise multiple regression was applied to select a model in which all variables are significant (Table 4), it was concluded that the numbers of Sarcophaga carnaria maggots were affected by both of temperature and humidity and the numbers of Wohlfahrtia magnifica maggots were affected by temperature. However, the numbers of Muscina stabulans maggots were affected by humidity. The weight of corpse was affected by the numbers of Sarcophaga carnaria, Chrysomya albiceps and Muscina stabulans maggots. 


\section{Forensic Catches:}

\section{Discussion}

The present results indicated that the maximum number of forensic species was represented by the dipterous insects (12 species). However, the second and third important forensic orders were represented by Coleoptera (3 species) and Hymenoptera (3 species), respectively. According to the species forensic importance, the insects recorded in this study were divided into four categories. The first category includes the greatest number of necrophagous individuals that fed directly on the cadavar. The most important necrophagous species were represented by Chrysomya albiceps, Lucilia cuprina, Sarcophaga carnaria, Wohlfahrtia magnifica, Muscina stabulans, Megaselia scalaris and Dermestes vulpinus. The second category comprises predators and parasites of the necrophagous species. Among the predators of particular significance were maggots of Chrysomya albiceps. Chrysomya albiceps maggots were not only fed on the cadavar but also were reported as predators on other larvae infesting the cadavar. These results are consistent with the results presented by Tantawi et al. (1996) and Pérez et al. (2005). This explains the occurrence of dead maggots of Sarcophaga carnaria and Wohlfahrtia magnifica near the cadavar throughout the experiments. Also predators include species in the families Staphylinidae and Histeridae. Parasites include species in the families Pteromalidae and Chalcididae. The third category includes the omnivorous species Formicidae ants such as Camponotus maculatus that fed on both cadavar and associated arthropods. The fourth category consists of incidental or adventives species having no direct relationship to the carcass. These results were consistent with those documented by (Payne, 1965).

Calliphorid and Sarcophagid flies were the first colonizers to arrive and breed on rabbit carcasses. This finding was consistent with the results of other studies in different geographic areas (Smith, 1986; MonteiroFilho \& Penereiro, 1987; Anderson \& Van Laerhoven, 1996 and Hall, 2001). They are strong fliers that can follow an odor plume over long distance and easily arrive and enter to corpses found enter buildings or at outdoor habitats (Erzinclioglu, 2006).

The present study showed that Sarcophaga carnaria was the most important component of insect succession on rabbit carcasses during all seasons because it was the most abundant species in all experiments. Agreeable results were presented by (Denno \& Cothran, 1976). In addition, larvae of Sarcophaga carnaria were collected in all seasons for two sites, larvae of Wohlfahrtia magnifica were collected in summer, spring and autumn at outdoor site and in summer and autumn at indoor site, larvae of Chrysomya albiceps were collected in spring and autumn and in summer and autumn at outdoor and indoor sites, respectively, larvae of Lucilia cuprina were collected in autumn only for two sites, larvae of Muscina stabulans were collected in autumn, winter and spring at indoor site only and larvae of Megaselia scalaris were collected at indoor autumn only. Although Sarcophagid larvae were coexisting with those of Calliphoridae on the same cadavar, Calliphoridae maggots were responsible for minimum consumption of rabbit carrion. These results were convenient with Tantawi et al. (1996). However, contrary to our results, Early \& Goff (1986) reported that the numbers of Sarcophagid larvae were much less than those of Calliphoridae. Consequently, calliphorid maggots ranked second regarding the reduction of carrion weight.

Sarcophagid species were frequently observed larvipositing on carcass at approximately the same time at the calliphorid species. This finding is consistent with the results of Early \& Goff (1986). The emanating results from our study clarified that the development duration of larval and pupal stages in the blowflies was shorter than that in the flesh flies and hence, the time of development in blowflies is faster than in flesh flies. This finding is convenient with (Shiravi et al., 2011). It is worthy to mention that not all species of flies visited the cadaver to put eggs or larvae. Musca domestica was found visiting, copulating, and feeding on the substrate or using it as an extension of its habitat. This observation was convenient with Dear (1978) and De Souza \& Linhares (1997). Similarly, Atherigona varia (Muscidae), Physiphora demandata (Otitidae), Anopheles coustani (Culicidae), Scatella sp. (Ephydridae), Sepsis fissa (Sefsidae) were collected as adult only as they visited the carrion to feed not to breed.

The emanating results clarified that flies prefer an oviposition at natural body openings (mouth, nose, and anus) and also hairy areas of the body. This may be due to the high moisture and lower intensity of light. The preference of flies to these areas for oviposition was also observed by Norris (1965). However, injuries and blood on a cadaver are more attractive sites for fly colonization than the natural openings. This observation is convenient with (Rodriguez \& Bass, 1983).

Megaselia scalaris is a common cosmopolitan species and more reported in indoor habitats and cooler seasons (Tantawi et al., 1996; Greenberg \& Wells, 1998; Reibe \& Madea, 2010; Thevan et al., 2010; Bugelli et al., 2015). It was coexisted with other sarcosaprophagous dipterans on the same corpse (Kumara et al., 2012; Bugelli et al., 2015). Hence, in the absence of other sarcosaprophagous species, it can be a sole indicator to help in solving the criminal cases (Campobasso et al., 2004; Bugelli et al., 2015; zuha et al., 2015). Nasonia sp. is a small polyphagous parasitic species, living in different habitats, and which may parasitize on several Cyclorrhapha dipterans and lay its eggs inside the pupae of flies. This is convenient with (Legner, 1967; Darling 
\& Werren, 1990; Blanchot, 1994/1995). If the time elapsed since death exceeds the immature developmental time of necrophagous species, Nasonia can estimate the time elapsed since death more precisely.

\section{Seasonal Field Flacutations:}

The diversity and density of insects collected in outdoor habitat was a slightly more than in indoor habitat. This result may be due to that the distribution of decay odors at outdoor was faster and easier than that in indoor and consequently the insects colonize the outdoor corpses faster than indoor corpses. However, this is contrary to Goff (1991) which observed more dipteran species in indoor compared to outdoor and Ahmed et al. (2011) which he recovered slightly more dipteran species in indoor habitat compared to outdoor. This may be due to the difference in study region.

In outdoor habitat, two families of coleoptera with two species of beetles were collected compared to three families of coleoptera with three species of beetles were in indoor habitat. This is convenient with the result of Ahmed et al. (2011). However, in contrast with Goff (1991) who reported more coleopteran species in outdoor habitat compared to indoor. Delaying of insect infestation to corpse resulted in significantly retarded and incomplete cadaver decomposition, consequently, there is inter-dependence between insect colonization and the decomposition rate. This observation was recorded by many researchers (Payne, 1965; Abell et al., 1982; Anderson \& Van Laerhoven, 1996; Simmons et al., 2010). This could explain why the cadaver took more time for decomposition in winter rather than other seasons.

Season and cadaver microenvironment are also factors influencing the species composition and successional patterns during carcass decomposition (Hanski, 1987). In comparison to other studies have been done in spring and summer season in relation to the diversity number. The collected insect species were less in diversity than other authors (Reed, 1958; Payne, 1965; Rodriguez \& Bass, 1983; Lord \& Burger, 1984; Early \& Goff, 1986; De Jong \& Chadwick, 1999; Watson \& Carlton, 2003; Grassberger \& Frank, 2004 and Arnaldos et al., 2004a) in the similar seasons. Such contrast agrees with Tentawi et al. (1996) and Galal et al. (2009) studies where they collected only 4-5 species during the hot summer. Therefore we could assume that the high temperature, which had been also recorded in the our current study, had accelerated the decomposition process, meaning that the cadaver is reduced to bones in a shorter time period leading to rapid depletion of food resource and reduction of arthropod colonization time particularly at outdoor habitat.

Decomposition rate of cadaver is affected by the changes in temperatures and humidity (Lopes de Carvalho \& Linhares, 2001; Kočárek 2003; Matoba \& Terazawa, 2008). In our study, there were no significant differences in humidity between seasons, unlike the temperature between seasons. The decomposition rate required longer time in seasons with lower temperatures. Consequently, we could deduced that humidity affected the decomposition rate less than temperature. This is convenient with (Kočárek, 2003). Temperature also affects the insect population dynamics and activity due to its control of growth and reproduction (de la Fuente et al., 2006).

The decomposition rate of corpses at outdoor habitat was significantly faster than that at indoor habitat for all seasons. This is due to high temperature and early insect colonization at outdoor habitat than at indoor habitat. The speed of decomposition rate was determined by the insect colonization and climatic conditions particularly temperature (Anderson, 2009). Goddard \& Lago (1985) stated that when temperature is high, the decomposition process becomes short. Results of the present study indicated that the carrions in summer and spring decayed at a much faster than those in fall and winter at both habitats. This result was convenient with Tantawi et al. (1996). In contrast with Ibrahim et al. (2013) which he stated that carrions in summer and fall decayed a much faster than in spring and winter.

In the present study, the total number of insect species collected in summer was a few less than in other seasons. The same as the results from Tantawi et al. (1996) and Watson \& Carlton (2005). This is due to succession in warmer seasons was driven by the rapid resource depletion because the corpses decomposed faster due to the higher temperatures. However, succession in cooler seasons was much influenced by the cold temperatures and rainfall which retarded the corpse decomposition and also the insect succession, hence a larger numbers of insect species were attracted to cadaver (Tantawi et al., 1996). However, in contrast with our results, Reed (1958), Johnson (1975) and Rodriguez \& Bass (1983) found that the corpse fauna was richer in warmer seasons than in cooler seasons.

\section{Statistical Analysis:}

Statistical analysis of the present results clarified that Sarcophaga carnaria maggots were affected negatively by temperature and humidity. In this study, we found that Sarcophaga carnaria maggots have been dead when the exposure to high temperatures in summer up to $47.4^{\circ} \mathrm{C}$ and also at the exposure to low temperatures and high humidity up to 50\%. As Woodmorappe (1998) stated, Sarcophaga sp. life development is temperature-dependent. Sam (2006) found that Sarcophaga sp. larvae that were exposed to the outside environment's cold temperature (low of $4^{\circ} \mathrm{C}$ ) all died the first night of initial exposure because no movement was 
detected the next day. He suggested that Sarcophaga sp. cannot survive in a cold temperature climate unless there was some source to provide them heat or incubation, such as a dead body or animal carcass. Also, Ward's Manual (2001) stated that the developmental rates of Sarcophaga sp. are temperature and light dependent which Cooler temperatures and less light exposure will slow down the growth of development. From the present study, we found that Wohlfahrtia magnifica maggots were affected positively by temperature which the speed of development increased with the increasing of temperatures, thus, the developmental time decreased. This is consistent with (Tantawi et al., 1996) who stated that Wohlfahrtia larvae in summer which temperature is high, developed rapidly and pupariated earlier. Our statistic results clarified that Muscina stabulans maggots were affected negatively by temperature and positively by humidity. Consequently, Muscina was observed at the indoor site only which temperature is low and humidity is high and due to the preference of Muscina to the shaded areas. This observation is agreement with the result of Patitucci (2010). In contrast with Linhares (1981) who observed the preference of Muscina to sunny areas. Studies on the succession of insects associated with dead bodies in special microenvironments are significant for their contribution in the development of forensic science, as well as their acting as a potential forensic tool in cases of human carrions found indoors and outdoors.

\section{Conclusions}

This investigation demonstrated that the patterns of decomposition and insect succession varied across different seasons and habitats. Ambient temperature and humidity were critical factors in the determination of the rate of decay in various seasons. Furthermore, the seasonal distribution of insect species significantly impacted the species that were recovered from cadaver in different times of the year. Insect species arrive on the cadaver in a predictable sequence which depends on the stages of decomposition, although the pattern varied in different times of the year and in the different habitats. Although a large number of insect species were observed at the cadavers, relatively a few used the cadaver for breeding purposes. This indicates that the insect species differ in their ability to use the different resources provided by the carrion. Generally, the first species of flies to colonize the carcass had an important advantage over later arriving species, and their larvae had a greater chance to develop to the adult stage. Both of Calliphoridae and Sarcophagidae species demonstrated a preference for the dark putrefaction stage of decay (Stage III), although they were found in the early and late stages of decomposition.

The present study shows there are two species of Sarcophagidae (Sarcophaga carnaria and Wholfahrtia magnifica), also two species of Calliphoridae (Chrysomya albiceps and Lucilia cuprina), one species of Muscidae (Muscina stabulans) and one species of Phoridae (Megaselia scalaris), that can be considered of potential forensic importance and can be used as indicators of postmortem interval (PMI) in Qena governorate, Egypt because they are able to breed on a cadaver. However, the most important of these species was Sarcophaga carnaria because it was the most frequent and abundant and the primary colonizer on the decomposing rabbit cadavers in the various habitats. Coleopteran species such as (Saprinus gilvicornis, Dermestes vulpinus and Atheta sp.) and hymenopteran species such as (Chalcis sp. and Nasonia sp.) dominated in later stages of decay, although their presence and colonization times varied across season and habitats. Not all species visited the cadaver only to oviposit or larviposit, but some species were found visiting, copulating and feeding on the cadaver tissues. The involvement of the present study in legal investigation enabled the investigators and the officials to be familiar with and aware of the importance of forensic entomology and as well initiated their interest in more information and further studies in this field. This study also highlights the importance of forensic entomology in Qena city, Egypt.

Finally, we can conclude that this study represents the first step in presenting forensic entomology as a science and a new discipline in Qena city, Egypt. We hope that this work may through light on the important role of the entomologist and the value of entomological information in legal investigations to be used as evidence in the court. The data generated from this work are now available for homicide investigations in Qena city and similar biogeoclimatic regions.

\section{References}

[1] Abell, D. H., Wasti, S. S. and Hartmann, G. C. (1982): Saprophagous arthropod fauna associated with turtle carrion. Appl. Entl. Zool., 17: 301-307.

[2] Ahmad, N. W.; Lim, L. H.; Dhang, C. C.; Chin, H. C.; Abdullah, A. G.; Mustaffa, W. N. W.; Kian, C. W.; Jeffery, J.; Hashim, R. and Azirun, S. M. (2011): Comparative insect fauna succession on indoor and outdoor monkey carrions in a semi-forested area in Malaysia. Asian Pacific J. Trop. Biomed., 1(2): S232-S238.

[3] Anderson, G. S. (1995): The use of insects in death investigations: an analysis of forensic entomology cases in British Columbia over a five year period. Can Soc Forensic Sci. J., 28(4): 277-92.

[4] Anderson, G. S. (1997): The use of insects to determine the time of decapitation: a case study from British Columbia. J. Forensic Sci., 42(5):947-50.

[5] Anderson, G. S. (2000b): Insect succession on carrion and its relationship to determining time of death. In: Byrd and Castner (Eds.). Forensic Entomology: The Utility of Arthropods in Legal Investigations. Boca Raton, CRC Press. 
[6] Anderson, G. S. (2009): Factors that influence insect succession on carrion. In: Byrd JH, Castner JL (eds.) Forensic entomology: The utility of arthropods in legal investigations. $2^{\text {nd }}$ ed. Boca Raton, FL: CRC Press, pp. 201-250.

[7] Anderson, G. S. and Van Laerhoven, S. L. (1996): Initial studies on insect succession on carrion in southwestern British Columbia. J. Foren. Sci., 41(4): 617-625.

[8] Archer, M. S. and Elgar, M. A. (2003): Yearly activity patterns in southern Victoria(Australia) of seasonally active corpse insects, Forensic Sci. Int., 132: 173-176.

[9] Arnaldos, M. I.; Romera, E.; Presa, J. J.; Luna, A. and García M. D. (2004a): Studies on seasonal arthropod succession on carrion in the southeastern Iberian Peninsula. Int. J. Leg. Med., 118(4): 197-205.

[10] Blanchot, P. (1994/1995): Inventaire des Parasitoïdes de Mouche synanthropes recensés en France, EPHE Biologie et Evolution des Insectes. 7/8: 111-119.

[11] Bonacci, T. (2016): The Contribution of the Insect Succession in the Medico-Criminal Entomology Context. Entomol. Ornithol. Herpetol., 5:2.

[12] Bugelli, V.; Forni, D.; Bassi, L. A.; Paolo, M. D.; Marra, D.; Lenzi, S.; Toni, C.; Giusiani, M.; Domenici, R.; Gherardi, M. and Vanin, S. (2015): Forensic Entomology and the Estimation of the Minimum Time Since Death in Indoor Cases. J. Forensic Sci., 60(2): 525-531.

[13] Campobasso, C. P.; Disney, R. H. L. and Introna, F. (2004): A case of Megaselia scalaris (Loew) (Dipt, Phoridae) breeding in a human corpse. Aggrawal's Internet J. Forensic Med. Toxicol., 5(1):3-5.

[14] Chen, C. P.; Denlinger, D. L. and Lee, R. E. (1991): Seasonal variation in generation time, diapause and cold hardiness in a central Ohio population of the flesh fly, Sarcophaga bullata, Ecol. Entomol., 16: 155-162.

[15] Darling, D. C. and Werren, J. H. (1990): Biosystematics of Nasonia (Hymenoptera: Pteromalidae): Two New Species Reared from Birds' Nests in North America. Ann. Entomol. Soc. Am., 83: 352-370.

[16] De Carvalho, L. M. L. and Linhares, A. X. (2001): Seasonality of insect succession and pig carcass decomposition in a natural forest area in southeastern Brazil. J. Foren. Sci., 46(3): 604-608.

[17] De Jong, G. D. and Chadwick, J. W. (1999): Decomposition and arthropod succession on exposed rabbit carrion during summer at high altitudes in Colorado, USA. Journal of Medical Entomology, 36: 833-845.

[18] de la Fuente, E.; Lendardis, A. E.; Su'arez, S. A.; Gil, A. and Ghersa, C. M. (2006): Insect communities related to wheat and coriander cropping histories and essential oils in the Rolling Pampa, Argentina. European Journal of Agronomy, 24: 385-395.

[19] De Souza, A. M. and Linhares, A. X. (1997): Diptera and Coleoptera of potential forensic importance in southeastern Brazil: relative abundance and seasonality. Med. \& Vet. Entomol., 11(1): 8-12.

[20] Dear, J. P. (1978): Chapter 3. Some micro-habitats. carrion. In Stubbs, A dipterist's handbook. Amateur entomologist, A. \& Chandler P. (eds), 15: 79-82.

[21] Denno, R. F. and Cothran, W. R. (1976): Competitive interactions and ecological strategies of sarcophagid and calliphorid flies inhabiting rabbit carrion. Ann. Entomol. Soc. Amer., 69(1): 109-113.

[22] Dillon, L. C. (1997): insect succession on Carrion in Three Biogeoclimatic Zones in British Columbia. Dept. of Biological Sciences. Burnaby. B. C., Simon Fraser University: 76.

[23] Early, M. and Goff, M. L. (1986): Arthropod succession patterns in exposed carrion on the island of O'ahu, Hawaiian Islands, USA. J. Med. Entomol., 23(5): 520-531.

[24] Erzinclioglu, Y. Z. (2006): Blowflies. UK: Richmond Publishing.

[25] Galal, L. A. A.; Abd-El-hameed, S. Y.; Attia, R. A. H. and Uonis, D. A. (2009): An initial study on arthropod succession on exposed human tissues in Assiut, Egypt. Mansoura J. Forensic Med. Clin. Toxicol., 17(1).

[26] Goddard, J. and Lago, P.K. (1985): Notes on blow fly (Diptera: Calliphoridae) succession on carrion in Northern Mississippi. J. Entomol. Sci., 20(3): 312-317.

[27] Goff, M. L. (1991): Comparison of insect species associated with decomposing remains recovered inside dwellings and outdoors on the island of Oahu, Hawaii. J. Foren. Sci., 36(3): 748-753.

[28] Goff, M. L. (1992): Problems in estimation of postmortem interval resulting from wrapping of the corpse: A case study from Hawaii. J. Agric. Entomol., 9(4):237-43.

[29] Goff, M. L. and Flynn, M. M. (1991): Determination of postmortem interval by arthropod succession: A case study from the Hawaiian Islands. J. Forensic Sci., 36:607-14.

[30] Goff, M. L. and Odom, C. B. (1987): Forensic entomology in the Hawaiian Islands, U.S.A. Three case studies. Am. J. Forensic Med. Pathol., 8:45-50.

[31] Goff, M. L.; Charbonneau, S. and Sullivan, W. (1991): Presence of fecal matter in diapers as potential source of error in estimations of postmortem intervals using arthropod development patterns. J. Forensic Sci., 36(5):1603-6.

[32] Goff, M. L.; Odom, C. B. and Early, M. (1986): Estimation of postmortem interval by entomological techniques: a case study from Oahu, Hawaii. Bull Soc Vector Ecol., 11:242-6.

[33] Goff, M. L.; Omori, A. I. and Gunatilake, K. (1988): Estimation of postmortem interval by arthropod succession. Three case studies from the Hawaiian Islands. Am. J. Forensic Med. Pathol., 9:220-5.

[34] Grassberger, M. and Frank, C. (2004): Initial study of arthropod succession on pig carrion in a central European urban habitat. Journal of Medical Entomology, 41: 511-523.

[35] Greenberg, B. (1985): Forensic entomology: case studies. Bull Entomol. Soc Am., 31(4):25-8.

[36] Greenberg, B. and Wells, J. D. (1998): Forensic use of Megaselia abdita and M. scalaris (Phoridae: Diptera): case studies, development rates, and egg structure. J. Med. Entomol., 35:205-9.

[37] Hall, R. D. (2001): Introduction: perceptions and status of forensic entomology. Forensic entomology: The utility of arthropods in legal investigations. Boca Raton CRC Press, $1^{\text {st }}$ ed., 1-15.

[38] Hall, R. D. and Doisy, K. E. (1993): Length of time after death - effect on attraction and oviposition or larviposition of midsummer blow flies (Diptera, Calliphoridae) and flesh flies (Diptera, Sarcophagidae) of medicolegal importance in Missouri. Annals of the Entomological Society of America, 86: 589-593.

[39] Hanski, I. (1987): Carrion fly community dynamics: patchiness, seasonality and coexistence. Ecol. Entomol., 12(3): 257-266.

[40] Henssge, C.; Madea, B.; Knight, B.; Nokes, L. and Krompecher, T. (1995): The estimation of the Time Since Death in the Early Postmortem Interval. Arnold, 262.

[41] Ibrahim, A. A.; Galal, F. H.; Seufi, A. M. and Elhefnawy, A. A. (2013): Insect succession associated with corpse's decomposition of the guinea pig Cavia porcellus in Benha city, Egypt. Egypt Acad. J. Biolog. Sci., 5 (1): 1- 20.

[42] Introna, J. r.; Altamura, F.; Dell'Erba, B. A. and Dattoli, V. (1989): Time since death definition by experimental reproduction of Lucilia sericata cycles in growth cabinet. J. Foren. Sci., 34(2): 478-480.

[43] Johnson, M. D. (1975): Seasonal and microseral variations in the insect populations on carrion. Am. Midl. Nat., 93: 79-90. 
[44] Kashyap, V. K. and Pillai, V. V. (1986): Cadaver insects as indicators of time of death: a few case studies. J. Police Res Dev Quarter, IV: 19-23.

[45] Kashyap, V. K. and Pillai, V. V. (1989): Efficacy of entomological method in estimation of postmortem interval: a comparative analysis. Forensic Science International, 40:245-250.

[46] Kočárek, P. (2003): Decomposition and Coleoptera succession on exposed carrion of small mammal in Opava, the Czech Republic. Europ. J. Soil Biol., 39(1): 31-45.

[47] Kumara, T. K.; Disney, R. H. L.; Abu Hassan, A.; Flores, M.; Tan, S. H. and Mohamed Z. et al. (2012): Occurrence of oriental flies associated with indoor and outdoor human remains in the tropical climate of north Malaysia. J. Vector Ecol., 37(1):62-8.

[48] Leclercq, M. and Vaillant, F. (1992): Forensic entomology: An original case. Ann. Soc. Entomol. France, 28(1):3-8.

[49] Legner, E. F. (1967): The status of Nasonia vitripennis as a natural parasite of the house fly, Musca domestica. Canadian Entomologist, 99(3): 308-309.

[50] Linhares, A. X. (1981): Sinantropy of Calliphoridae and Sarcophagidae in the city of Campinas, SP, Brazil. Revista brasileira de Entomologia, 25: 189-215.

[51] Lopes de Carvalho, L. M. and Linhares, A. X. (2001): Seasonality of insect succession and pig carcass decomposition in a natural forest area in southeastern Brazil. Journal of Forensic Sciences, 46: 604-608.

[52] Lord, W. D. and Burger, J. F. (1984): Arthropods associated with herring gulls (Larus argentatus) and great black-backed gulls (Larus marinus) carrion on islands in the gulf of Maine. Environ. Entomol., 13(5): 1261-1268.

[53] Lord, W. D.; Adkins, T. R. and Catts, E. P. (1992): The use of Synthesiomyia nudesita (Van Der Wulp) (Diptera: Muscidae) and Calliphora vicina (Robineau-Desvoidy) (Diptera: Calliphoridae) to estimate the time of death of a body buried under a house. J. Agric. Entomol., 9(4):227-35.

[54] Lord, W. D.; Catts, E. P.; Scarboro, D. A. and Hadfield, D. B. (1986a): The green blowfly, Lucilia illustris (Meigen) as an indicator of human postmortem interval: a case of homicide from Fort Lewis, Washington. Bull Soc. Vector Ecol., 11(2):271-5.

[55] Lord, W. D.; Goff, M. L.; Adkins, T. R. and Haskell, N. H. (1994): The black soldier fly Hermetia illucens (Diptera: Stratiomyidae) as a potential measure of human postmortem interval: observations and case histories. J. Forensic Sci., 39(1):215-22.

[56] Lord, W. D.; Johnson, R. W. and Johnson, F. (1986b): The blue bottle fly Calliphora vicina (5erythrocephala) as an indicator of human postmortem interval: a case of homicide from suburban Washington, D.C. Bull Soc. Vector Ecol., 11: 276-80.

[57] Mann, R. W.; Bass, W. M. and Meadows, L. (1990): Time since death and decomposition of the human body: variables and observations in case and experimental field studies, J. Forensic Sci. 35: 103-111.

[58] Matoba, K. and Terazawa, K. (2008): Estimation of the time of death of decomposed or skeletonised bodies found outdoors in cold season in Sapporo city, located in the northern district of Japan. Legal Med., 10(2): 57-114.

[59] Monteiro-Filho, E. L. A. and Penereiro, J. L. (1987): Estudo de decomposição e sucessão sobre uma carcaça animal numa área do Estado de São Paulo, Brasil. Rev. Bras. Biol., 47: 289-95.

[60] Norris, R. R. (1965): The bionomics of blowflies. Ann. Rev. Entomol., 10(1): 47-68.

[61] Patitucci, L. D.; Mulieri, P. R.; Mariluis, J. C. and Schnack, J. A. (2010): The Population Ecology of Muscina stabulans (Fallén) (Diptera: Muscidae), along an Urban-Rural Gradient of Buenos Aires, Argentina. Entomology, 39(3):441-446.

[62] Payne, J. A. (1965): A summer carrion study of the baby pig Sus scrofa Linnaeus. Ecol., 46(5): 592-602.

[63] Pérez, S.P.; Duque, P. and Wolff, M. (2005): Successional behavior and occurrence matrix of carrion-associated arthropods in the urban area of Medellín, Colombia. J. Foren. Sci., 50(2): 448-453.

[64] Reed, H. B. (1958): A study of dog carcass communities in Tennessee, with special reference to the insects. The American Midland Naturalist, 59(1): 213-245.

[65] Reibe, S. and Madea, B. (2010): Use of Megaselia scalaris (Diptera: Phoridae) for post-mortem interval estimation indoors. Parasitol. Res., 106:637-40.

[66] Rodriguez, W. C. and Bass, W. M. (1983): Insect activity and its relationship to decay rates of human cadavers in East Tennessee. J. Foren. Sci., 28(2): 423-432.

[67] Sam, S. (2006): A Study of the Effect of Temperature on the Developmental Rate of Flesh Flies, Sarcophaga sp. Saint Martin's University Biology Journal., 1: 233-243.

[68] Shiravi, A. H.; Mostafavi, R.; Akbarzadeh, K. and Oshaghi, M. A. (2011): Temperature Requirements of Some Common Forensically Important Blow and Flesh Flies (Diptera) under Laboratory Conditions. Iran J. Arthropod-Borne Dis, 5(1): 54-62.

[69] Simmons, T.; Adlam, R. E. and Moffatt, C. (2010): Debugging decomposition data-comparative taphonomic studies and the influence of insects and carcass size on decomposition rate. J. Foren. Sci., 55(1): 8-13.

[70] Smith, K. G. V. (1986): A manual of forensic entomology. The trustees of british museum of natural history. London and Comstock Publishing Associates, New York, 1-205.

[71] Tantawi, T. I.; El-Kady, E. M.; Greenberg, B. and El-Ghaffar, H. A. (1996): Arthropod succession on exposed rabbit carrion in Alexandria, Egypt. J. Med. Entomol., 33(4): 566-580.

[72] Tessmer, J. W. and Meek, C. L. (1996): Dispersal and distribution of Calliphoridae (Diptera) immatures from animal carcasses in southern Louisiana. Journal of Medical Entomology, 33: 665-669.

[73] Thevan, K.; Disney, R. H. L. and Ahmad, A. H. (2010): First records of two species of Oriental scuttle flies (Diptera: Phoridae) from forensic cases. Forensic Sci. Int., 195:e5-7.

[74] Tullis, K. and Goff, M. L. (1987): Arthropod succession in exposed carrion in a tropical rainforest on O'ahu Island, Hawai'i. J. Med. Entomol., 24: 332-339.

[75] Ward's Manual (2001): Working with Nasonia. pp. 1-2. Ward's Natural Science Establishments, Inc., Rochester, NY.

[76] Watson, E. J. and Carlton, C. E. (2003): Spring succession of necrophilous insects on wildlife carcasses in Louisiana. J. Med. Entomol., 40(3): 338-347.

[77] Watson, E. J. and Carlton, C. E. (2005): Insect succession and decomposition of wildlife carcasses during fall and winter in Louisiana. Journal of Medical Entomology, 42: 193-203.

[78] Williams, H. and Richardson, A. M. M. (1984): Growth energetics in relation to temperature for larvae of four species of necrophagous flies (Diptera: Calliphoridae). Australian Journal of Ecology, 9: 141-152.

[79] Woodmorappe, J . (1998): The creationist significance of flesh flies. <http://www.rae.org/flies.html>. 21 Apr. [accessed 2005 Dec. 05]

[80] Zuha, R. M.; Ankasha, S. J.; Disney, R. H. L. and Omar, B. (2015): Indoor decomposition study in Malaysia with special reference to the scuttle flies (Diptera: Phoridae). Egyptian Journal of Forensic Sciences, 1-7. 
Table (1): The collected forensic insects from the indoor and outdoor rabbit corpses during the different seasons from October 2013 to September 2014:

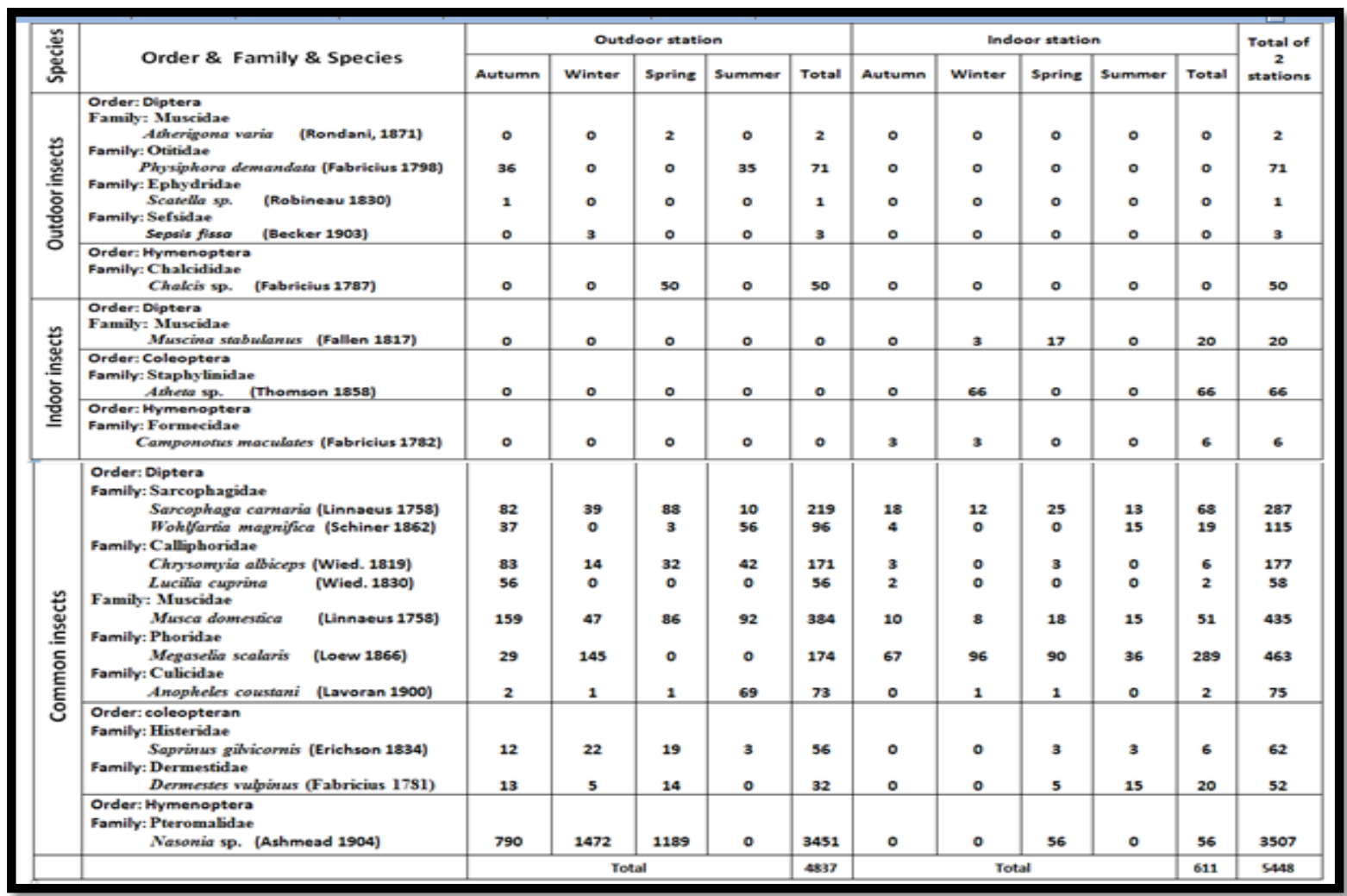

Table (2): Decay rates of rabbit corpses placed outdoor and indoor in different seasons from October 2013 to September 2014:

\begin{tabular}{|c|c|c|c|c|c|c|}
\hline \multirow[b]{2}{*}{ Season } & \multirow[b]{2}{*}{ Habitat } & \multicolumn{5}{|c|}{ Days postmortem } \\
\hline & & Fresh & Bloating & Active decay & Advanced decay & Dry \\
\hline \multirow{2}{*}{ Autumn } & Outdoor & $\mathbf{0}$ & $1-2$ & $3-4$ & $5-9$ & $10-25$ \\
\hline & Indoor & $0-1$ & $2-4$ & $5-7$ & $8-14$ & $15-30$ \\
\hline \multirow{2}{*}{ Winter } & Outdoor & $0-5$ & $6-10$ & $11-14$ & $15-20$ & $21-45$ \\
\hline & Indoor & $0-5$ & $6-12$ & 13-18 & $19-27$ & $28-49$ \\
\hline \multirow{2}{*}{ Spring } & Outdoor & $0-1$ & 2 & $3-4$ & $5-7$ & 8-22 \\
\hline & Indoor & $0-1$ & $2-3$ & $4-5$ & $6-11$ & $12-24$ \\
\hline \multirow{2}{*}{ Summer } & Outdoor & $\mathbf{0}$ & 1 & 2 & 3 & 4-16 \\
\hline & Indoor & $\mathbf{0}$ & 1 & $2-3$ & $4-6$ & $7-19$ \\
\hline
\end{tabular}

Table (3): Correlation coefficients for association between different species and physical factors during the period of experiment.

\begin{tabular}{|c|c|c|c|}
\hline & & Temperature & Humidity \\
\hline Sarcophaga carnaria & $\begin{array}{l}\text { R } \\
\text { Sig. }\end{array}$ & $\underset{N \times}{-0.130}$ & $\begin{array}{c}-0.057 \\
\text { NS }\end{array}$ \\
\hline Wohlfahrtia magnifica & $\begin{array}{l}\text { R } \\
\text { Sig. }\end{array}$ & $\begin{array}{c}0.298 \\
\star \star x\end{array}$ & $\underset{\star \star}{-0.144}$ \\
\hline Clorysomya albiceps & $\begin{array}{l}\text { R } \\
\text { Sig. }\end{array}$ & $\begin{array}{c}0.039 \\
\text { NS }\end{array}$ & $\begin{array}{c}-0.045 \\
\text { NS }\end{array}$ \\
\hline Lucilia cuprina & $\begin{array}{l}\text { R } \\
\text { Sig. }\end{array}$ & $\begin{array}{c}0.013 \\
\text { NS }\end{array}$ & $\begin{array}{c}-0.001 \\
\text { NS }\end{array}$ \\
\hline Muscina stabulans & $\begin{array}{l}\text { R } \\
\text { Sig. }\end{array}$ & $\underset{\star \star}{-0.170}$ & $\underset{\star \star}{0.234}$ \\
\hline Megaselia scalaris & $\begin{array}{l}\text { R } \\
\text { Sig. }\end{array}$ & $\begin{array}{c}0.000 \\
\text { NS }\end{array}$ & $\begin{array}{c}0.037 \\
\text { NS }\end{array}$ \\
\hline
\end{tabular}


Table (4): Stepwise multiple regression between the numbers of different species with the physical factors:

\begin{tabular}{|c|c|c|c|c|c|c|c|c|c|}
\hline \multirow[t]{2}{*}{ Dependent variable } & \multirow{2}{*}{$\begin{array}{l}\text { Selected } \\
\text { variable }\end{array}$} & \multirow{2}{*}{$\mathbf{R}$} & \multirow{2}{*}{ R2 } & \multirow{2}{*}{\begin{tabular}{c|} 
Std. \\
error of \\
the \\
Estimate
\end{tabular}} & \multicolumn{2}{|c|}{$\begin{array}{l}\text { Unstandardized } \\
\text { Coefficients }\end{array}$} & \multirow{2}{*}{$\begin{array}{c}\begin{array}{c}\text { Standardized } \\
\text { Coefficients }\end{array} \\
\text { Beta }\end{array}$} & \multirow{2}{*}{$\mathrm{t}$} & \multirow{2}{*}{ Sig. } \\
\hline & & & & & B & $\begin{array}{l}\text { Std. } \\
\text { error }\end{array}$ & & & \\
\hline \multirow{3}{*}{ Sarcophaga carnaria } & (constant) & \multirow{3}{*}{0.182} & \multirow{3}{*}{0.033} & \multirow{3}{*}{224.47725} & 372.292 & 61.880 & & 6.016 & 0.000 \\
\hline & Temperature & & & & -5.901 & 1.322 & -0.193 & -4.462 & 0.000 \\
\hline & Humidity & & & & -4.735 & 1.440 & -0.142 & -3.290 & 0.001 \\
\hline \multirow{2}{*}{ Wohlfahrtia magnifica } & (constant) & \multirow{2}{*}{0.298} & \multirow{2}{*}{0.089} & \multirow{2}{*}{245.96585} & -227.378 & 37.772 & & -6.020 & 0.000 \\
\hline & Temperature & & & & 10.298 & 1.302 & 0.298 & 7.909 & 0.000 \\
\hline \multirow{2}{*}{ Muscina stabulanus } & (constant) & \multirow{2}{*}{0.234} & \multirow{2}{*}{0.055} & \multirow{2}{*}{62.46069} & -41.395 & 9.117 & & -4.541 & 0.000 \\
\hline & Humidity & & & & 2.199 & 0.360 & 0.234 & 6.109 & 0.000 \\
\hline \multirow[t]{4}{*}{ Weight } & (constant) & \multirow{4}{*}{0.310} & \multirow{4}{*}{0.096} & \multirow{4}{*}{136.28949} & 194.601 & 5.867 & & 33.167 & 0.000 \\
\hline & S. carnaria & & & & 0.151 & 0.024 & 0.241 & 6.385 & 0.000 \\
\hline & M. stabulanus & & & & 0.332 & 0.084 & 0.149 & 3.962 & 0.000 \\
\hline & C. albiceps & & & & 0.321 & 0.140 & 0.086 & 2.288 & 0.022 \\
\hline
\end{tabular}

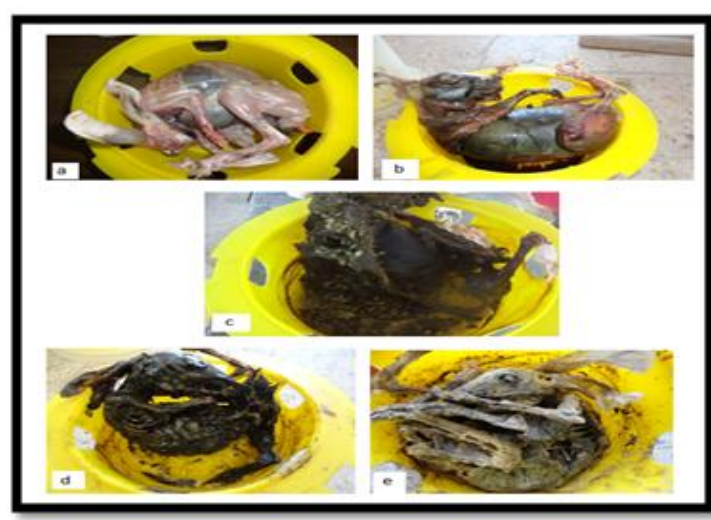

Fig. (1): Decomposition stages of rabbit corpse at outdoor environment from October 2013 to September 2014 in Qena governorate, Egypt. (a) Fresh stage. (b) Bloating stage. (c) Active decay stage. (d) Advanced decay stage. (e) Dry stage.

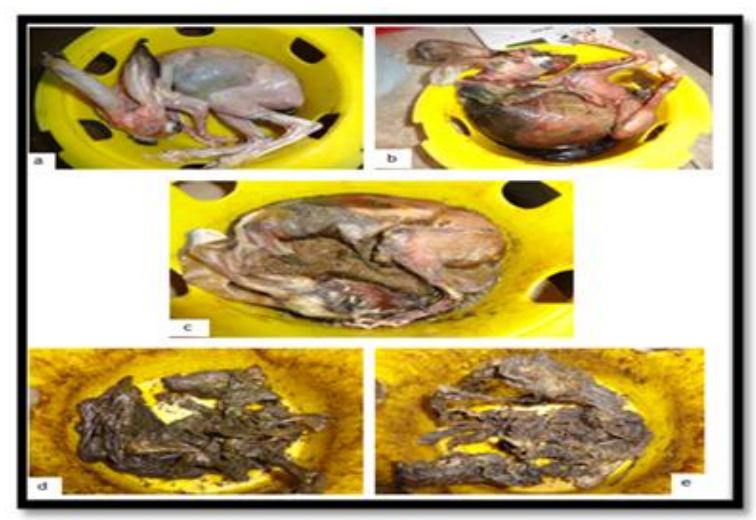

Fig. (2): Decomposition stages of rabbit corpse at indoor environment from October 2013 to September 2014 in Qena governorate, Egypt. (a) Fresh stage. (b) Bloating stage. (c) Active decay stage. (d) Advanced decay stage. (e) Dry stage.

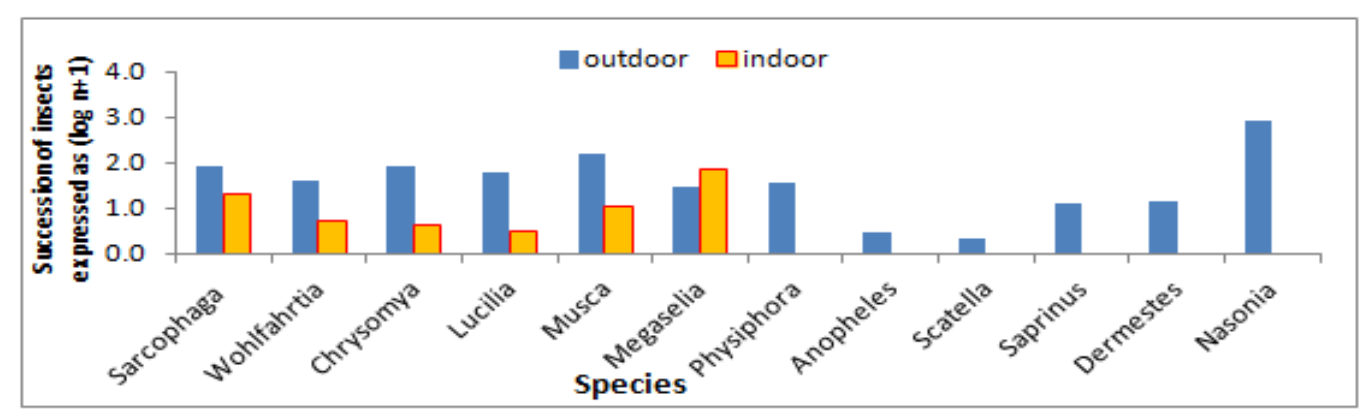

Fig. (3): succession of forensic insect species on rabbit corpses placed indoor and outdoor during autumn 2013.

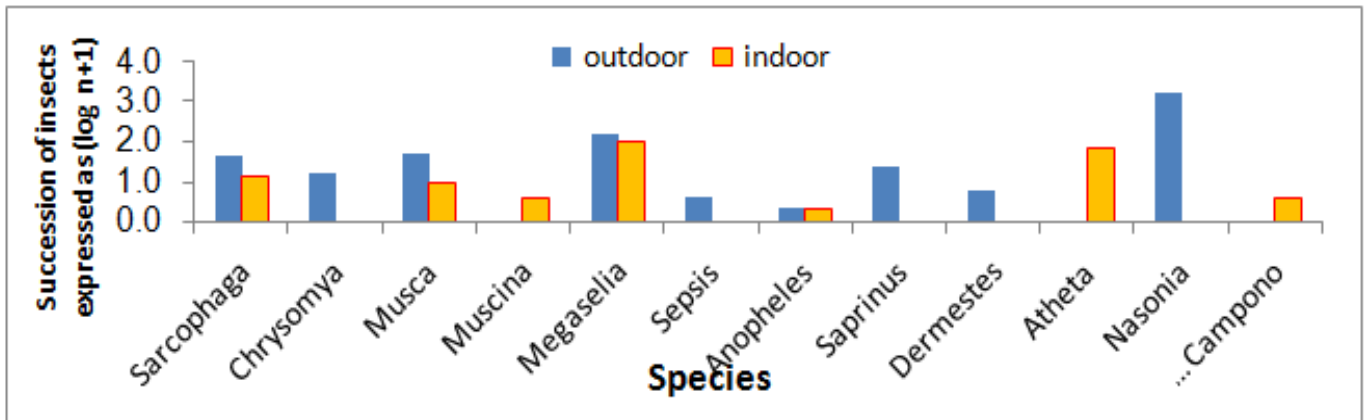

Fig. (4): Succession of forensic insect species on rabbit corpses placed indoor and outdoor during winter 2014. 


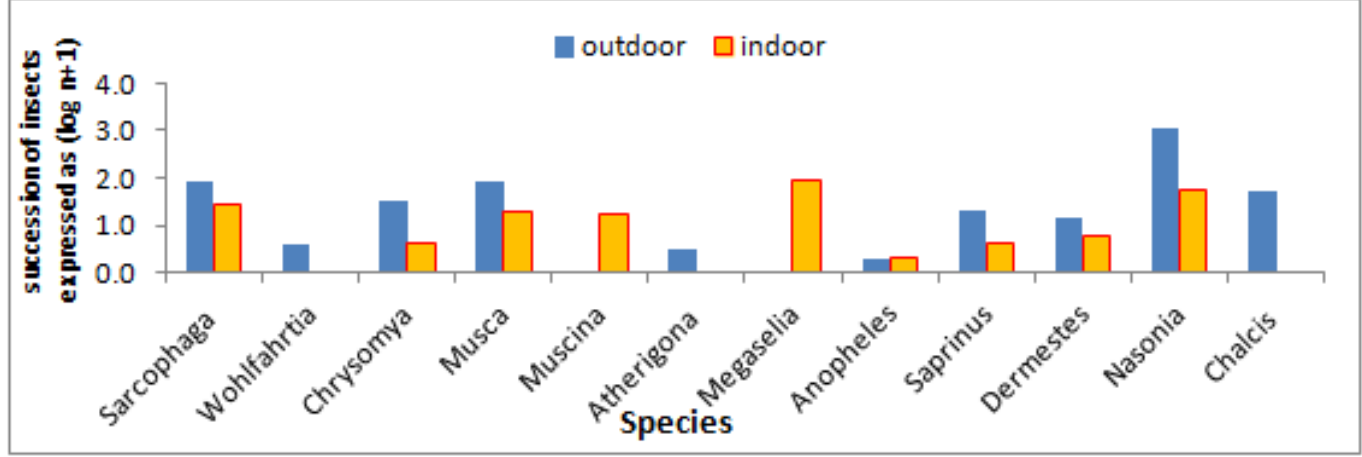

Fig. (5): Succession of forensic insect species on rabbit corpses placed indoor and outdoor during spring 2014.

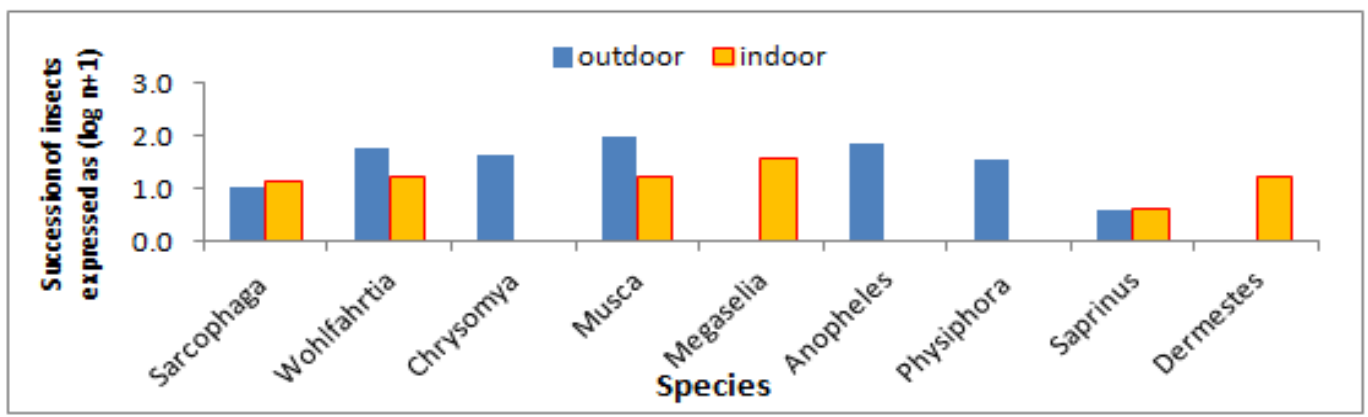

Fig. (6): Succession of forensic insect species on rabbit corpses placed indoor and outdoor during summer 2014.

Necrophagous species

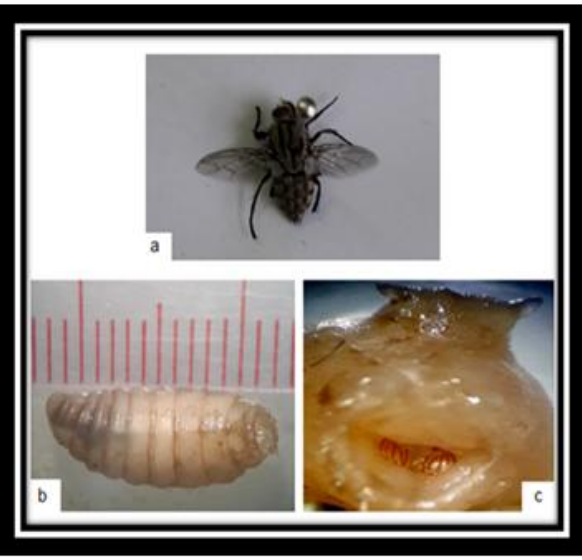

Fig.(7):Sarcophaga carnaria (Diptera)

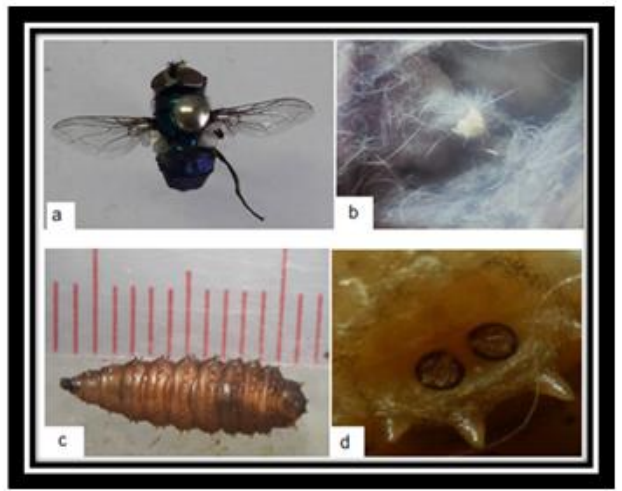

Fig.(9): Chrysomya albiceps (Diptera)

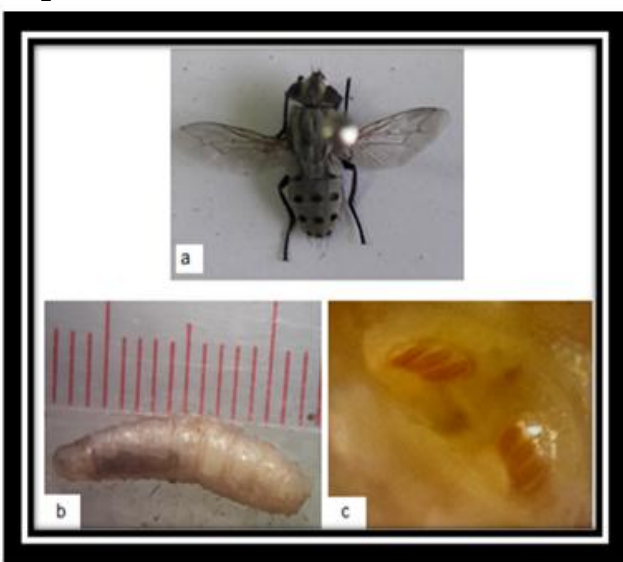

Fig.(8): Wohlfahrtia magnifica (Diptera)

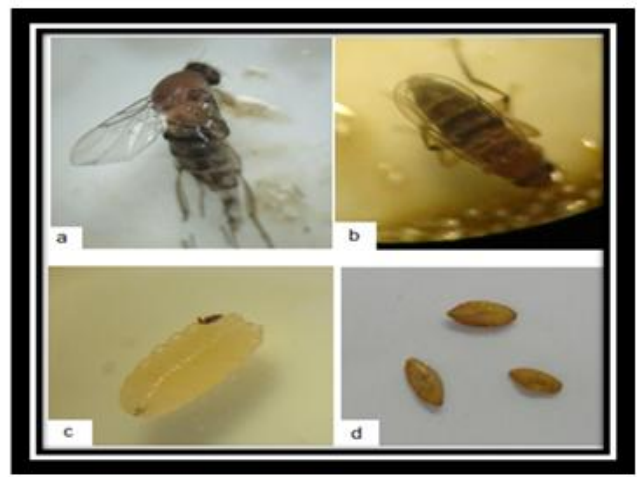

Fig.(10): Megaselia scalaris (Diptera) 


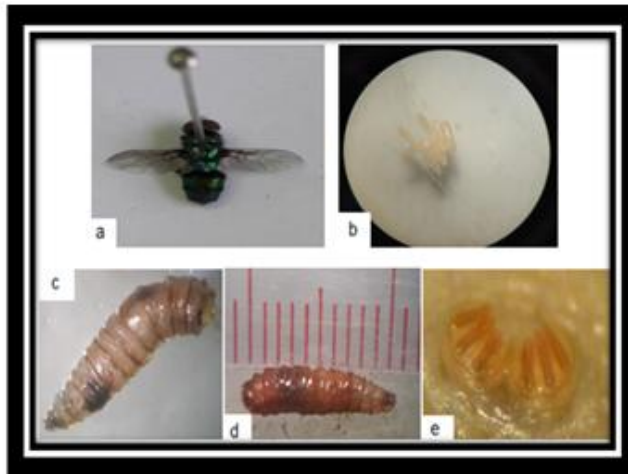

Fig.(11):Lucilia cuprina (Diptera)

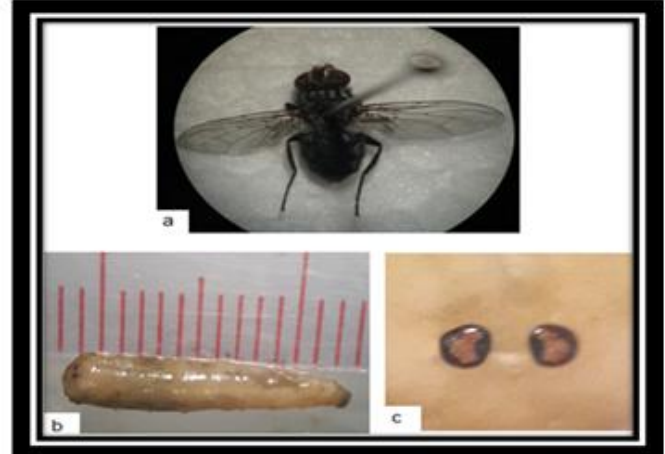

Fig.(12): Muscina stabulans (Diptera)

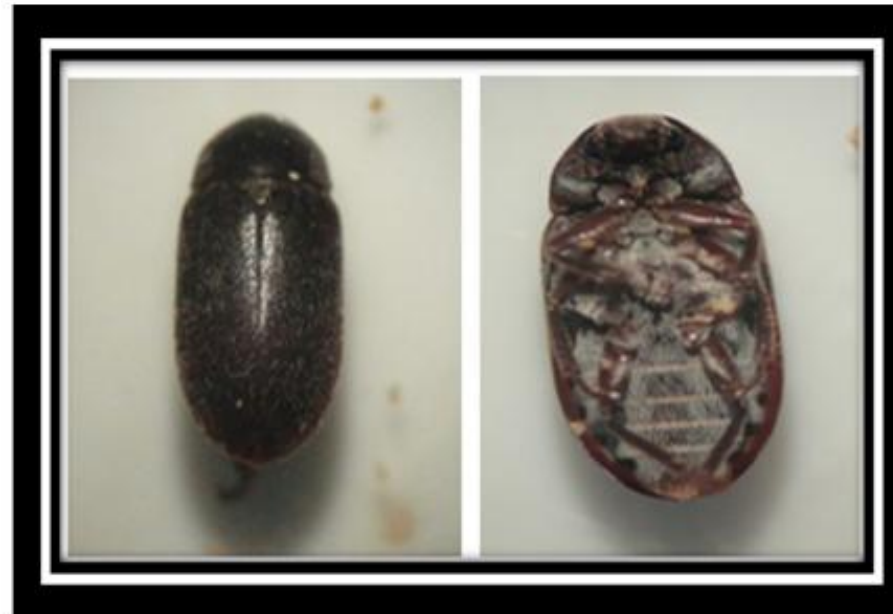

Fig.(13): Dermestes vulpinus (Coleoptera)

Necrophalous species

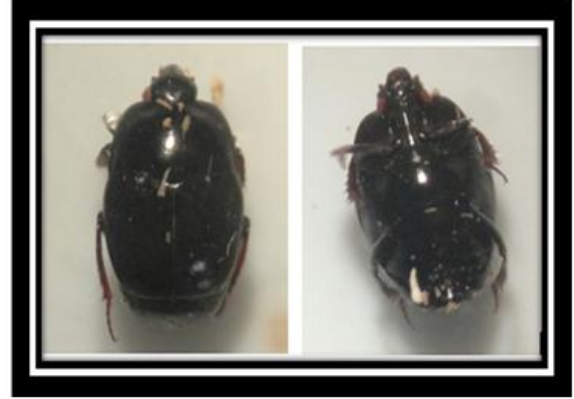

Fig.(14): Saprinus gilvicornis (Coleoptera)

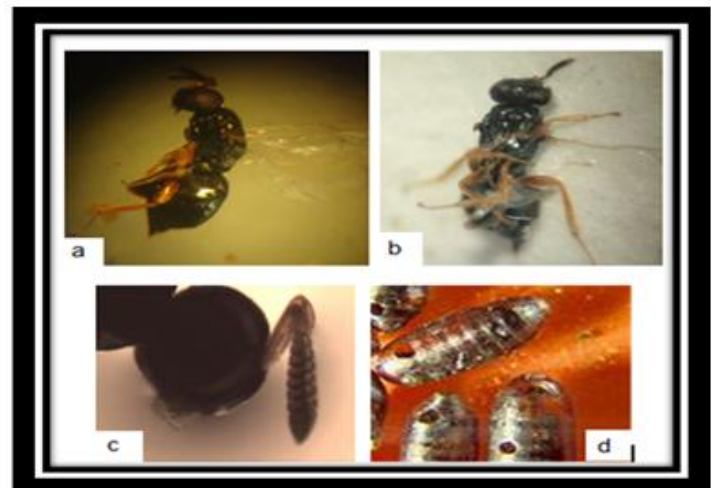

Fig.(16): Nasonia sp. (Hymenoptera)

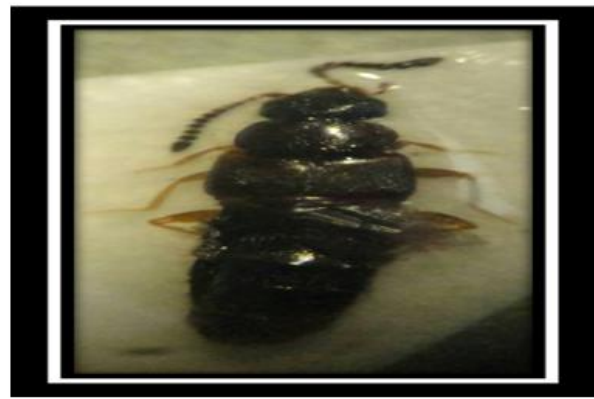

Fig.(15): Atheta sp. (Coleoptera)

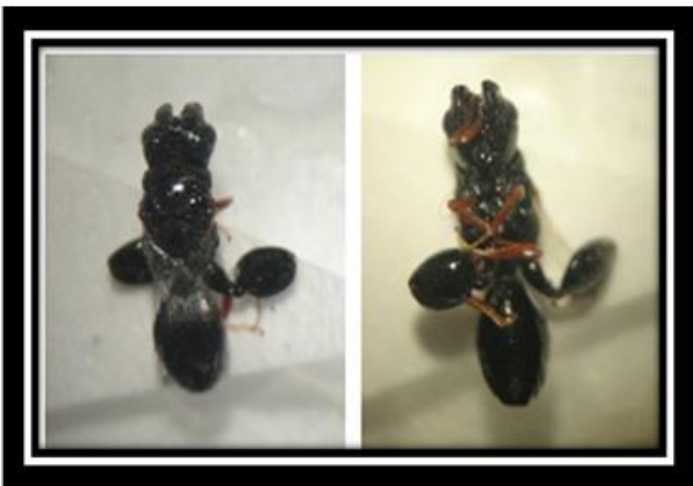

Fig.(17): Chalcis sp. (Hymenoptera) 
Omnivorous species

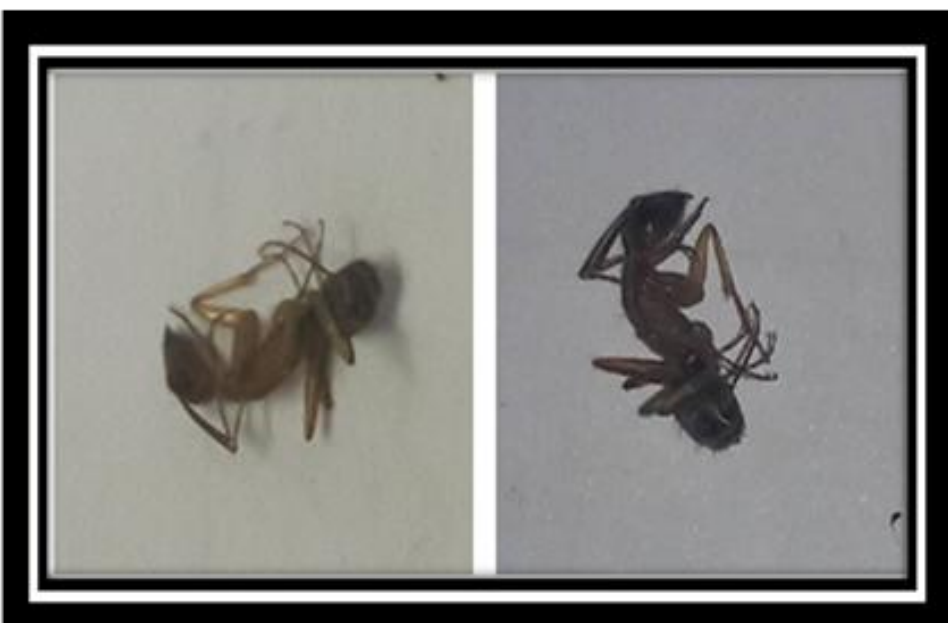

Fig.(18): Camponotus maculates (Hymenoptera)

Accidental species

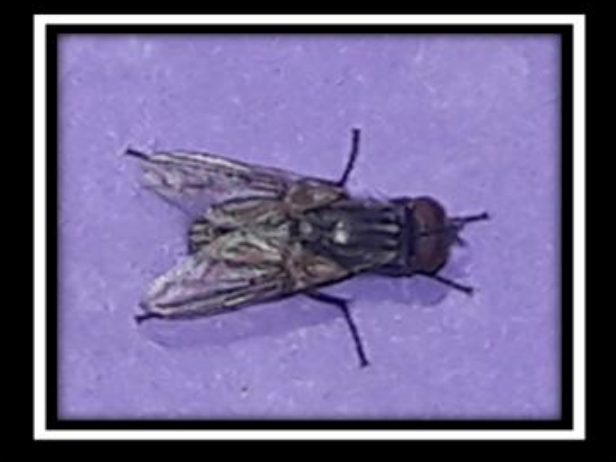

Fig.(19): Musca domestica (Diptera)

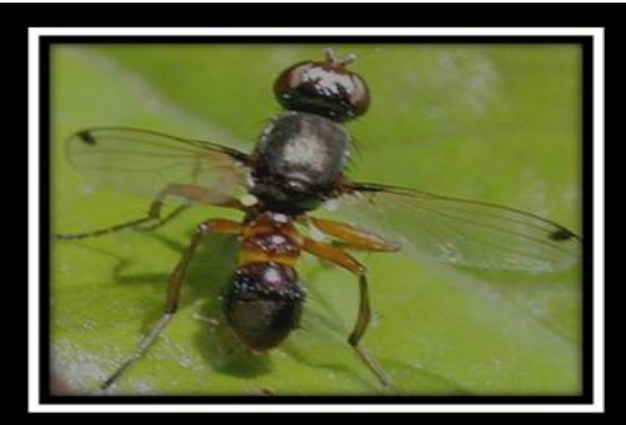

Fig.(21): Sepsis fissa (Diptera)

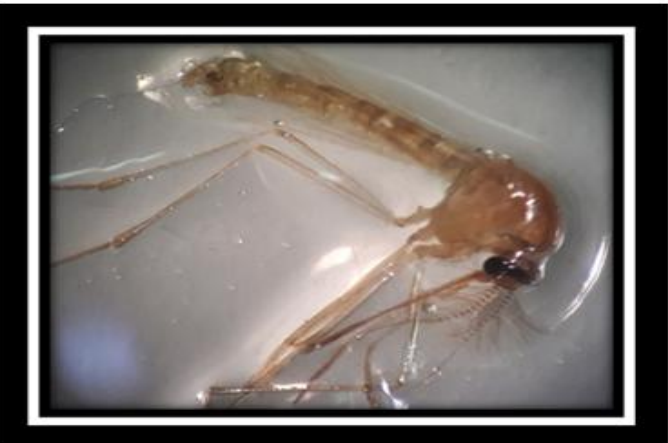

Fig.(23): Anopheles coustani (Diptera)

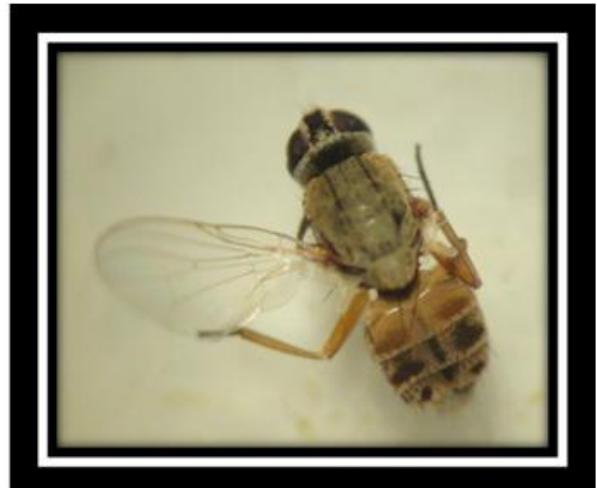

Fig.(20): Atherigona varia (Diptera)

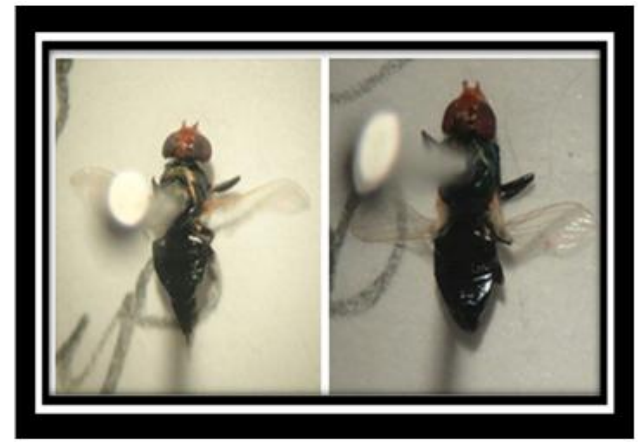

Fig.(22): Physiphora demandata (Diptera)

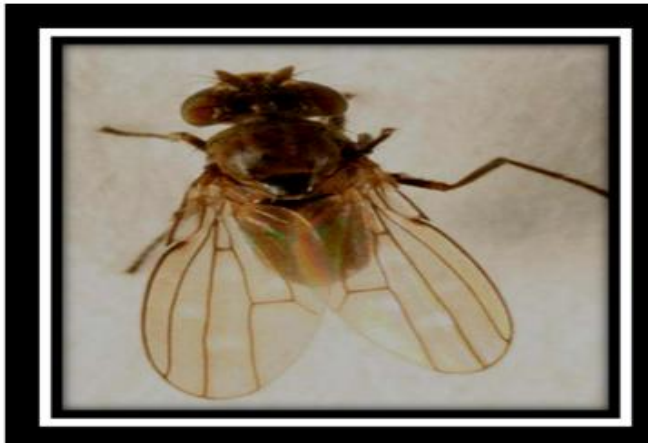

Fig.(24): Scatella sp. (Diptera) 